\title{
Hypoglycaemic effect of Croton cuneatus in streptozotocin-induced diabetic rats
}

\author{
Fatima Torrico $^{1}$, Mariana Cepeda ${ }^{1}$, Geraldine Guerrero ${ }^{1}$, Fidel Melendez ${ }^{1}$, Zuleima Blanco ${ }^{1}$, \\ Dilsia J. Canelón ${ }^{1}$, Beth Diaz ${ }^{1}$, Reinaldo S. Compagnone ${ }^{2 *}$, Alírica I. Suárez ${ }^{1}$
}

\author{
${ }^{1}$ Facultad de Farmacia, Universidad Central de Venezuela, Apdo 40109, \\ Caracas, Venezuela, \\ ${ }^{2}$ Escuela de Quimica, Facultad de Ciencias, Universidad Central de Venezuela, \\ Caracas, Venezuela,
}

\begin{abstract}
RESUMO: "Efeito hipoglicêmico de Croton cuneatus em ratos diabéticos induzido por estreptozotocina”. A ação hipoglicemiante do extrato aquoso das cascas do caule de Croton cuneatus Klotz (Euphorbiaceae) foi investigada em ratos com diabetes induzida pela estreptozotocina (STZ). Doses crescentes do extrato aquoso (6,5, 13, 26 e $52 \mathrm{mg} / \mathrm{kg}$ i.p.) foram administradas separadamente a grupos de animais normais e diabéticos em jejum. Foram avaliadas as concentrações plasmáticas de glicose e colesterol, assim como mudanças no peso corporal. A administração crônica intraperitoneal (i.p.) do extrato durante 22 dias induziu uma redução significativa nos níveis de glicose sanguínea. Foi feita uma comparação entre o extrato aquoso de C. cuneatus e a droga de referência glibenclamida. Os resultados desse experimento indicam que esta planta possui atividade antidiabética em modelo com animais hiperglicêmicos.
\end{abstract}

Unitermos: Croton cuneatus, estreptozotocina, açúcar no sangue, efeito antihiperglicémico.

\begin{abstract}
Aqueous extract of the stem barks of Croton cuneatus Klotz (Euphorbiaceae) was investigated for hypoglycaemic activity in streptozotocin(STZ)-induced diabetic rats. Increasing doses of aqueous extract (6.5, 13, 26 and $52 \mathrm{mg} / \mathrm{kg}$ i.p.) were separately administered to groups of fasted normal and diabetic rats. Plasma glucose concentration, cholesterol and changes in body weight were evaluated. The chronic intraperitoneal (i.p.) administration of the extract for 22 days was found to induce significant reduction in blood glucose level. A comparison was made between the action of the aqueous extract of $C$. cuneatus and the reference standard drug glibenclamide. The results of this experimental animal study indicate that this plant has an antidiabetic activity in hiperglycaemic rat models.
\end{abstract}

Keywords: Croton cuneatus, streptozotocin, blood glucose, antihyperglycemic effect.

\section{INTRODUCTION}

Diabetes mellitus (DM) is an endocrine disorder characterized by hyperglycemia and glycosuria due to absolute or relative lack of insulin. In 2004 according to WHO, more than 150 million people worldwide suffer from diabetes. Its incidence is increasing with alarming mortality and morbidity, and it is estimated that by the year 2025 the number of people with this disease will be double (WHO 1999, Boyle et al., 2001, Wild et al., 2004). There is an increasing demand of new antidiabetic products due to the drawbacks associated with insulin and oral hypoglycemic agents actually available (Fertig et al., 1995, Yariura-Tobias et al., 2001). Lowering the concentration of glucose in blood is the best defense against complications due to diabetes such as: blindness, renal failure and limb amputation (Mayfield, 1998). In folk medical practice around the world, many plants have been used to treat diabetes (Bayley; Day 1989; Ivorra et al., 1989; Barbosa-Filho et al., 2005; Agra et al., 2007).
Most of these medicinal plants are not scientifically validated, for their therapeutic efficacy and safety uses. The World Health Organization has also recommended the evaluation of the effectiveness of the numerous medicinal plants used by the people in different countries to get relief from diabetes mellitus (WHO 1980).

C. cuneatus is commonly known in Venezuela as "arapurina" and "caferana". The plant is attributed with medicinal properties for the indigenous people, such as: relief of gastrointestinal disorders, rheumatism and diabetes. The isolation of three new alkaloids from the organic extracts of the leaves of $C$. cuneatus has been reported (Suárez et al., 2004). In the essential oil obtained from the leaf, 43 compounds has been described, being the major ones: $\alpha-11$ eudesmene, methyleugenol, 4$\alpha$-seleniol, cedryl propyl ether, $\tau$-cadinol and cubenol (Suárez et al., 2005a). Recently, we have determined the anti-inflammatory activity of an aqueous extract of the aerial parts of this plant (Suárez et al., 2005b), and to the best of our knowledgement, no other information 
about the pharmacological properties have yet appeared. The present study was undertaken to evaluate the hypoglycemic and antidiabetic properties of C. cuneatus stem bark aqueous extract in normal and streptozotocininduced diabetic rats. The results were also compared with glibenclamide as a reference drug.

\section{MATERIAL AND METHODS}

\section{Plant material}

Stem-barks of the plant $C$. cuneatus were collected in May 2003 from the Barinas State of Venezuela. The plant was identified and authenticated by Dr. Anibal Castillo, and a voucher specimen (AC6483) has been deposited in the Herbarium Ovalles of the Facultad de Farmacia of the Universidad Central of Venezuela.

\section{Preparation of the plant extract}

The aqueous extract was prepared by decoction. Stem-barks air-dried at room temperature were cut into small pieces, and powdered in a blender. $250 \mathrm{~g}$ of powder were mixed with $500 \mathrm{~mL}$ of distilled water and boiled for $15 \mathrm{~min}$. The aqueous extract was filtered and freeze-dried. The lyophilized, a dark-brown material was stored in a refrigerator at $5{ }^{\circ} \mathrm{C}$. Portions of this residue were weighed and suspended in distilled water daily, just before administration.

\section{Animals}

Young adult male albino rats (Sprague-Dawley strain) weighing 170 - 180g were used. The animals were housed in polypropylene cages in standard environmental conditions, $12 \mathrm{~h}$ light and $12 \mathrm{~h}$ dark cycle at $25 \pm 2{ }^{\circ} \mathrm{C}$. Before and during the experiments, the rats were fed with standard laboratory pellet diet and water ad libitum. Animals were treated according to international standards of animal's welfare (National Institutes of Health, 1996).

\section{Induction of diabetes}

Experimental diabetes was induced in rats by intraperitoneal administration of streptozotocin (Sigma, St Louis, MO, USA) at a dose of $50 \mathrm{mg} / \mathrm{kg}$ body weight (Verspohl, 2002). After $48 \mathrm{~h}$ of streptozotocin injection, blood glucose levels were estimated. Animals with blood glucose concentrations increasing by more of $40 \%$ were considered diabetic and were included in this study.

\section{Experimental design}

The study was conducted on 30 rats divided into six different groups of 5 rats each described as follows. Group I: Non-diabetics control. Rats maintained on

standard diet and water ad libitum; Group II: Diabetic control rats without treatment; Group III: Diabetic rats were given intraperitoneally dose of $\left(1 / 2 \mathrm{TD}_{50}\right) 52 \mathrm{mg} / \mathrm{kg}$ body weight of aqueous extract; Group IV: Diabetic rats were given intraperitoneally dose of $\left(1 / 4 \mathrm{TD}_{50}\right) 26 \mathrm{mg} / \mathrm{kg}$ body weight of aqueous extract; Group V: diabetic rats were given intraperitoneally dose of $\left(1 / 8 \mathrm{TD}_{50}\right) 13 \mathrm{mg} / \mathrm{kg}$ body weight of aqueous extract; Group V: Diabetic rats were given intraperitoneally dose of $\left(1 / 16 \mathrm{TD}_{50}\right) 6.5 \mathrm{mg} /$ kg body weight of aqueous extract; Group VI: Diabetic rats were given intraperitoneally dose of glibenclamide $5 \mathrm{mg} / \mathrm{kg}$.

The effects of the administration of the aqueous extract of $C$. cuneatus in the animals under study were determined in collected blood samples from the tail vein, the blood glucose lowering activity was observed after 2 , 4 , and $6 \mathrm{~h}$ of administration of single dose, this experiment was considered as an acute treatment.

The evaluation of the blood glucose levels was done each other day during 22 days after daily treatment with the different doses. Levels of blood glucose and serum cholesterol were determined in each sample. The blood samples were centrifuged at $5{ }^{\circ} \mathrm{C}$ for ten minutes at $5000 \mathrm{rpm}$ for serum separation. Serum samples were stored at $-20{ }^{\circ} \mathrm{C}$ for later determination of blood glucose and cholesterol. Blood glucose was estimated spectrophotometrically using a commercial kit. (Wiener $\left.\mathrm{Lab}^{\circledR}\right)$. Determination of total cholesterol was done according to colourimetric method (Stat Fax ${ }^{\circledR} 1904$ Plus).

\section{Statistical analysis}

All the data reported are expressed as mean \pm S.E.M.; statistical evaluation was performed using oneway analysis of variance (ANOVA), using computerized, software Statitix ${ }^{\circledR}$ followed by Student's $t$-test. The values were considered significantly different when $P$-value was less than 0.05 compared to baseline values.

\section{RESULTS}

\section{Body weight}

The effect of the intraperitoneal administration of aqueous extract of $C$. cuneatus on body weight during the chronic treatment for 22 days was not significant. Basal body weights of all groups were not significantly different. In STZ-diabetic rats, the treatment did not affect the body weight values. After 22 days of treatment, the body weights of all animals were not significantly different from the control group.

\section{Total cholesterol}

The plasma was separated from the blood samples after the collection from the tail vein. The chronic 
administration of the increasing doses of $C$. cuneatus aqueous extract did not show important changes in the levels of total cholesterol in the animals under study.

\section{Single administration of increasing doses on blood glucose levels}

Effects of a single intraperitoneal injection of the different doses of the aqueous extract of $C$. cuneatus on blood glucose levels, in normoglycaemic and STZdiabetic rats, are shown in Table 1. Induction of diabetes in the experimental rats was confirmed by the presence of high glucose levels; animals with blood glucose levels above $250 \mathrm{mg} / \mathrm{dL}$ were considered diabetics. After two, four and six hours following administration of the treatment, the blood glucose levels were determined. In STZ rats, the administration of the aqueous extract caused a significant progressive reduction on the blood glucose levels after $2 \mathrm{~h}$ of the administration. The maximal reductions in the blood glucose levels were observed at the plant extract dose of $13.0 \mathrm{mg} / \mathrm{kg}$. The doses of 13 and $6.5 \mathrm{mg} / \mathrm{kg}$ were as effective as the sulfonylurea drug, glibenclamide. At the dose of $13 \mathrm{mg} / \mathrm{kg}$ the blood glucose levels dropped from $344.57 \pm 63.32$ to $210.17 \pm 10.20$ $\mathrm{mg} / \mathrm{dL}(41.61 \%)$ after $2 \mathrm{~h}$, and from $344.57 \pm 63.32$ to $136.17 \pm 3.18 \mathrm{mg} / \mathrm{dL}$ (60.48 \%) after $6 \mathrm{~h}$. The dose of 6.5 $\mathrm{mg} / \mathrm{kg}$ reduced the glucose levels from $309.67 \pm 1.66$ to $195.9 \pm 19.1 \mathrm{mg} / \mathrm{dL}$ (36.73 \%) after $2 \mathrm{~h}$ and, from 309.67 \pm 1.66 to $153.77 \pm 26.61 \mathrm{mg} / \mathrm{dL}$ (50.34 \%) after $6 \mathrm{~h}$. The reference antidiabetic drug glibenclamide reduced the blood glucose levels from $330.33 \pm 29.42$ to $220.17 \pm$ $64.36 \mathrm{mg} / \mathrm{dL}$ (33.37\%) after $2 \mathrm{~h}$ and, from $330.33 \pm 29.42$ to153.77 $\pm 26.61 \mathrm{mg} / \mathrm{dL}$ (53.45 \%) after 6 h. These results show that the effectiveness of the aqueous extract of C. cuneatus at the mentioned doses was similar to the glibenclamide. The blood glucose levels of the untreated diabetic rats increased during 6 hours treatment.

\section{Chronic administration of graded doses}

Figure 1 shows the change in blood glucose levels by the chronic administration of $C$. cuneatus aqueous extract (52, 26, 13 and $6.5 \mathrm{mg} / \mathrm{kg}$ i.p.) for 22 days in STZ rats. Significant reduction in blood glucose levels was observed with all the administered doses, however this reduction became more pronounced with the lower doses. The antidiabetic effect was not found to be dose dependent as there was not significant differences between the 26, 13 and $6.5 \mathrm{mg} / \mathrm{kg}$ extract treated groups.

\section{DISCUSSION}

In the present study, the antihyperglycemic activity of increasing doses of aqueous extract of $C$. cuneatus was assessed in STZ-diabetic rats. The model of diabetic rats induced with STZ, is one of the most useful experimental to represent type II diabetes mellitus and is widely used in the evaluation of plants extracts (Pepato et al., 2002, Muruganandan et al., 2005, Husen et al., 2004). STZ destroy the pancreatic $\beta$ cells, which are the insulin secret cells located in the pancreas. The destruction of these $\beta$-cells, causes a persistent hyperglycemia (Hofteizer, 1973). Sulfonylureas such as glibenclamide, are the most widely used drugs for the treatment of type 2 diabetes, and appear to function by stimulating insulin secretion. The effect increases the responsiveness of $\beta$ cells, which result in more insulin released at all blood glucose concentrations (Groop, 1992); Sulfonylureas usually lower blood glucose concentrations by about 20 percent. The results of blood glucose levels in the STZdiabetic rats compared with the normal group confirmed the development of the hyperglycemia as result of STZ injection. Experimental evidence obtained in this animal study indicated that the aqueous extract of $C$. cuneatus shows hypoglycaemic properties similar to the used reference drug. The $C$. cuneatus extract significantly reduced the blood glucose levels between 50 and $60 \%(p$ $<0.001$ ) during the acute treatment, which indicated the strong hypoglycaemic effect. The diabetic animals used in the chronic treatment exhibited significant lowering of the blood glucose levels at the end of 22 days. Our results showed a marked difference between the initial and final levels of blood glucose levels of the different groups treated with the increasing doses of the $C$. cuneatus aqueous extract compared with the diabetic control group. The inter-daily administration for 22 days with the aqueous extract, nearly normalize the glucose levels of the different animals group, which could be interpreted as a cumulative action in the treatment time. The experimental data obtained during the chronic treatment, showed that the antidiabetic activity of $C$. cuneatus aqueous extract was not found dose dependent, as there was no significant differences between the 26,13 and $6.5 \mathrm{mg} / \mathrm{kg}$ extract on the treated groups. The obtained results in our study may suggest that the antihyperglycaemic activity of the aqueous extract of $C$. cuneatus, may be due to a stimulating insulin release from the remnant $\beta$ cells in the islets of Langerhans. This is the same mechanism exerted by the sulfonyl drugs as glibenclamide which involves an improvement in insulin action at cellular level. Another possible mechanism could also be due however, to a combination of all these effects (Jackson; Bressler, 1981). In order to reveal the possible mechanism of the shown effect a histological analysis of the pancreas, kidneys and liver, is currently under study in our lab.

\section{CONCLUSION}

A significant anti-hyperglycaemic activity in STZ diabetic rats was demonstrated, in which the action was exhibited in acute and chronic treatments. The low dose of the extract used $6.5 \mathrm{mg} / \mathrm{kg}$ and the duration of the treatment were enough to normalize the blood glucose levels in the diabetic animals. The effectiveness of the 
C. cuneatus extract was comparable with the results obtained with glibenclamide which was the drug used as reference in this study. The results of the study revealed the potential of the aqueous extract of $C$. cuneatus, in the treatment of no insulin-dependent diabetes mellitus.

\section{ACKNOWLEDGMENTS}

The authors wish to thank to Dr. E. Lopez Loyo for his useful discussion.

Table 1. Effect of different doses of aqueous extract of C. cuneatus on blood glucose levels (mg/dL) in streptozotocin induced diabetic rats. (Values given represent the mean S.E.M).

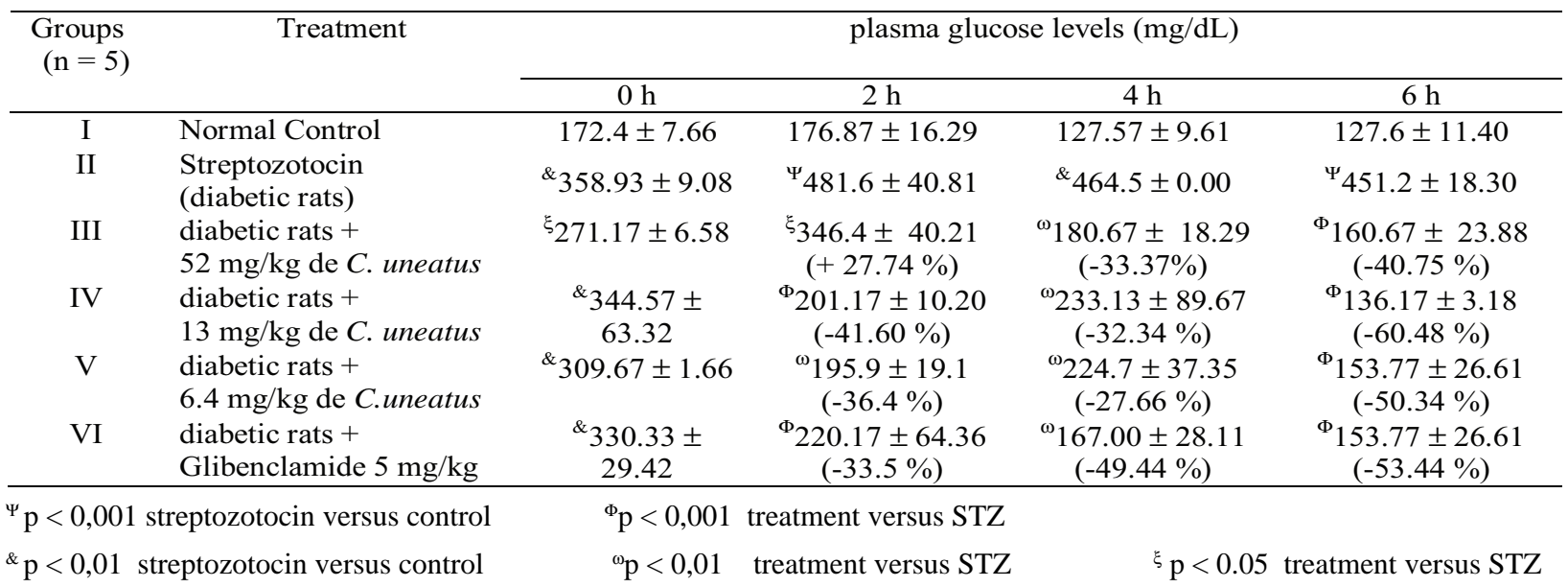

\section{REFERENCES}

Agra MF, França PF, Barbosa-Filho JM 2007. Synopsis of the plants known as medicinal and poisonous in Northeast of Brazil. Rev Bras Farmacogn 17: 114-140.

Barbosa-Filho JM, Vasconcelos THC, Alencar AA, Batista LM, Oliveira RAG, Guedes DN, Falcão HS, Moura MD, Diniz MFFM, Modesto-Filho J 2005. Plants and their active constituents from South, Central, and North America with hypoglycemic activity. Rev Bras Farmacogn 15: 392-413.

Bayley CJ, Day C 1989. Traditional plant medicines as treatments for diabetes. Diabetes Care 8: 553-564.

Boyle JP, Honeycutt AA, Narayan KM, Hoerger TJ, Geiss LS, Chen H, Thompson TJ 2001. Projection of diabetes burden through 2050: impact of changing demography and disease prevalence in the US. Diabetes Care 24: 1936-1940.

Fertig BJ, Simmon SDA, Marten MB 1995. Therapy for diabetes. Diabetes 95: 1468-1469.

Groop LC 1992. Sulfonylureas in NIDDM. Diabetes Care 15: 737-754.

Hofteizer V 1973. Comparison of streptozotocin-induced diabetes in the rat inducing volumetric quantitation of the pancreatic islets. Diabetologia 9: 178-184.

Husen R, Pihie AHL, Nallapan M 2004. Screening of antihyperglycaemic activity in several local herbs of Malasya. J Ethnopharmacol 95: 205-208.

Ivorra MD, Paya M, Villar A 1989. A review of natural products and natural plants as potential antidiabetic drugs. $J$ Ethnopharmacol 27: 243-275.

Jackson JE, Bressler R 1981. Clinical pharmacology of sulphonylurea hypoglycemic agents. Drugs 22: 211245.

Mayfield J 1998. Diagnosis and classification of Diabetes Mellitus: new criteria. Am Fam Physician 58: 1355-
1362.

Muruganandan S, Srinivasan K, Gupta S, Gupta PK, Lal J 2005. Effect of mangiferin on hyperglycemia and atherogenicity in streptozotocin diabetic rats. $J$ Ethnopharmacol 97: 497-501.

National Institutes of Health 1996. Guide for the Care and Use of Laboratory Animals. National Institutes of Health, National Academy Press, Washington, OC, USA.

Pepato MT, Keller H, Baviera M, Kettelhut IC, Vendramini RC, Brunetti IL 2002. Anti-diabetic activity of Bauhinia fortificata decoction in streptozotocin-diabetic rats. $J$ Ethnopharmacol 81: 191-197.

Suárez AI, Blanco Z, Delle Monache F, Compagnone RS, Arvelo F 2004. Three new glutarimide alkaloids isolated from Croton cuneatus. Nat Prod Res 18: 421-426.

Suárez AI, Vasquez L, Manzano M, Compagnone RS 2005a. Essential oil composition of Croton cuneatus and Croton malambo growing in Venezuela. Flavour Frag J 20: 611-614.

Suárez AI, Blanco Z, Compagnone RS, Salazar-Bookaman MM, Zapata V, Alvarado C 2005b. Anti-inflammatory activity of Croton cuneatus aqueous extract. $J$ Ethnopharmacol 105: 99-101.

Versphol EJ 2002. Recommended testing in diabetes research. Planta Med 68: 581-590.

WHO 1999. Expert Committee on Diabetes mellitus. Technical Report Series Number 138 and 236. World Health Organization, Geneva.

WHO 1980. Expert Committee on Diabetes mellitus. Technical Report Series, World Health Organization, Geneva.

Wild S, Roglic G, Green A, Sicree R, King H 2004. Global prevalence of diabetes. Diabetes Care 27: 1047-1053.

Yariura-Tobias JA, Pinto A, Neziroglu F 2001. Anorexia nervosa, diabetes mellitus, brain atrophy, and fatty liver. Int J Etiol Disorders 30: 350-353. 